\title{
Architecture of Small Type Train Station in Yogyakarta, Indonesia
}

\author{
Masyiana Arifah Alfia Riza1', Edy Darmawan¹, Ikaputra Ikaputra², Dimas Wihardyanto² \\ ${ }^{1}$ Department of Architecture, Faculty of Engineering, Universitas Diponegoro, Semarang, Indonesia \\ ${ }^{2}$ Universitas Gadjah Mada, Yogyakarta, Indonesia
}

Corresponding e-mail: arifah@arsitektur.undip.ac.id

\author{
Article info: \\ Received: 6-9-2021, Revised: 8-10-2021, Accepted: 25-10-2021
}

\begin{abstract}
The reason for the construction of the Ngabean (Yogyakarta)-Palbapang (Bantul)-Sewugalur (Kulon Progo) railway line with a length of $28 \mathrm{~km}$ was to accommodate four sugar factories along the line. In order to shorten the rail transport line on the Yogyakarta-Sewugalur railway line, 12 small stations were made. However, unfortunately, in 1942, this line was closed, causing some of these stations to be closed and disappear. Among the available stations are Winongo Station, Bantul Station, and Palbapang Station. This study aims to look at the characteristics of 18th century Dutch Indonesian architecture in the station building. Knowing the architectural character of the station building can play as a reference for maintaining the conservation of historical buildings in Indonesia. This study employed a rationalisticqualitative approach. To identify the architectural character of the station building, this study was conducted by looking at the spatial system, architectural system, and structural building system. From the study results, it was found that Winongo Station, Bantul Station, and Palbapang Station have a distinctive character both from the spatial system, architectural system, and structural system.
\end{abstract}

Keywords: architecture, conservation, heritage, indish, train station

\section{Introduction}

Colonial architecture in Indonesia is a unique cultural phenomenon because there is a mix of cultures between immigrants and diverse Indonesian cultures (Sumalyo, 1995). These architectural styles and concepts are adapted to the tropical climate and the availability of materials in Indonesia to obtain a new form that resembles the architectural shape in their country (Purnomo et al., 2017). Yogyakarta Province is a province with a colonial architectural heritage because, at the end of the 19th century, it became a pilot area for the construction of a railway network in Indonesia by the Dutch government (which was a colonizer at that time) because of its strategic location and potential natural resources for export commodities. The relatively fertile soil in Yogyakarta provides the potential for natural resources for plantations. At that particular time, the price of sugar in the world market was quite good, so that sugarcane plantations and sugar factories were opened. In Yogyakarta alone in 1870, there were 19 sugar factories (Pabrik Gula Di Yogya Tidak Hanya PG Madukismo Halaman 1 - Kompasiana.Com, 2017). The development of this sugar factory led to the establishment of a short-distance railway line. The railroad was the mainstay of public transportation, military mobilization, and transportation of the sugar industry. One of them is the Ngabean (Yogyakarta)-Palbapang (Bantul)- Sewugalur (Kulon Progo) line with a length of $28 \mathrm{~km}$ accommodating four sugar factories along the route. In order to shorten the rail transport line on the YogyakartaSewugalur railway line, 12 small stations were made. However, unfortunately, in 1942, this line was closed, causing some of these stations to be closed and disappear. Among the available stations are Winongo Station (Yogyakarta), Bantul Station (Bantul), and Palbapang Station (Bantul) (presented figure 1.1). 


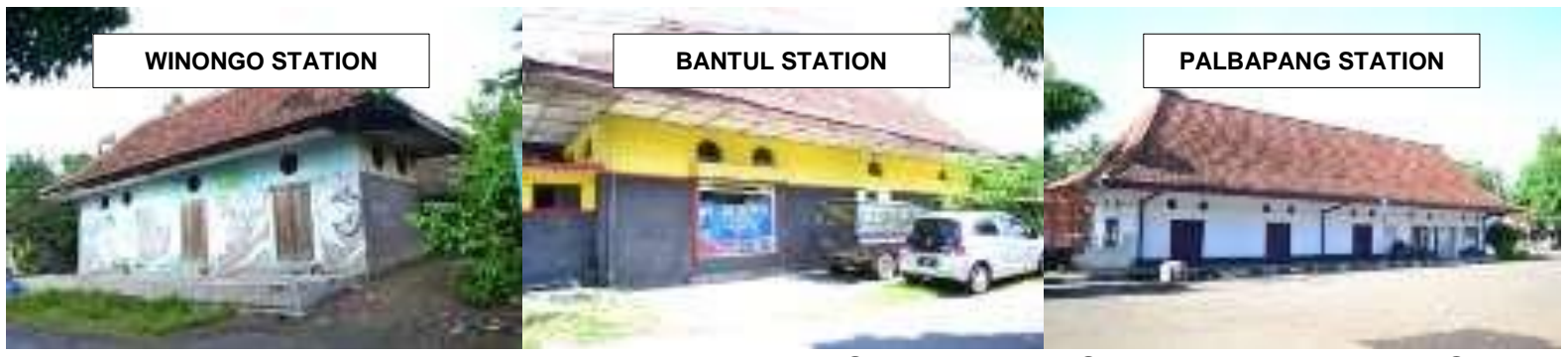

Figure 1. 1 Among the available stations are Winongo Station, Bantul Station, dan Palbapang Station (Authors, 2021)

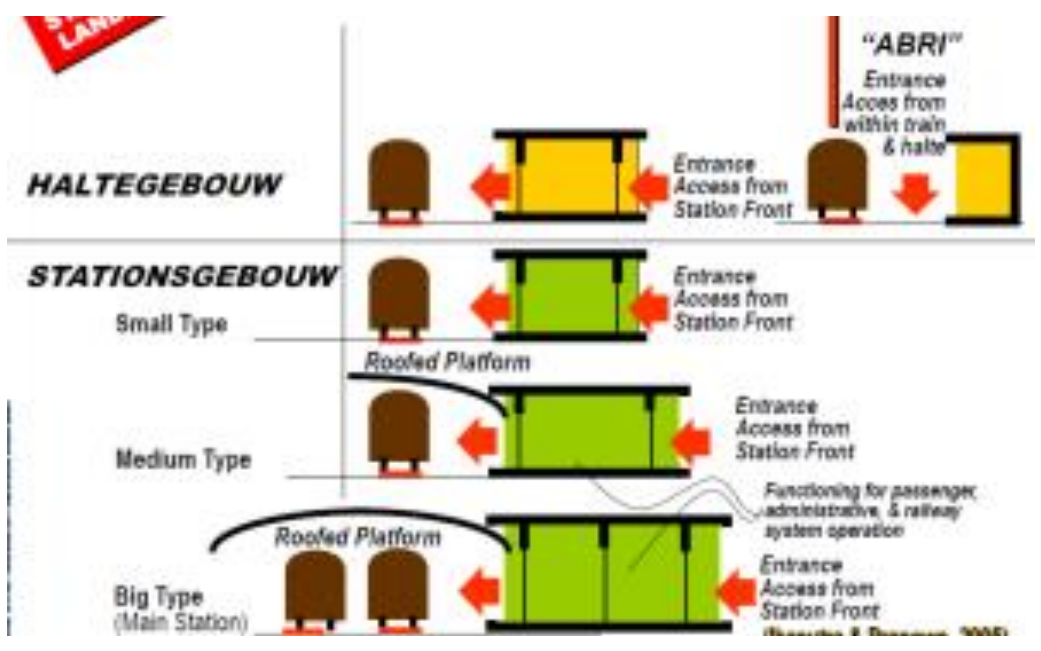

Figure 1. 2 Typology of Station Building (Lehner et al., 2013)

Figure 1.2 (Lehner et al., 2013) depicts the types of stations along the oldest railway tracks in Java connecting Semarang, Solo and Yogyakarta into two types: haltegebouw and stationgebouw. These two types of stations are described below

- The haltegebouw type is principally similar to the bus-stops called halte which can be found in many cities in Indonesia. The halte building functioned only as a place to wait for the train and for getting on and off the train. In the colonial era, most of the haltegebouw were small, simple rectangular buildings made of wood, and although some were of a similar form and layout as small stationgeboew, their function was as a train stop only (i.e. not for operating the train system itself). Several years after Independence the name of these haltegebouw changed to loket abri (abri = "counter"), with a small rectangular layout, with three partitions and one opening on the side nearest the tracks for access both from the train and the halte. Some haltegebouws have a ticket counter.

- The stationsgebouw type not only functioned as a waiting room (wachtkammer) but also had other functions such as a ticket counter (ruang kartjis and tilgraph), an offi ce for the station master, a station cafe, a train operator room / control room, a storage room, etc. According to Subarkah (1983), the stationgebouw can be categorized into a small, medium, and large station. The differences depended on station size and also on the complexity of the functions of the station related to its roles and capacity to serve passengers and for logistics transport. For example, a city station called Semut Station was the fi rst station in east Java, and it played a role as both a passenger hub and collection point for exporting local agricultural products from east Java to the Netherlands . 
From the results of the previous study, it was found by the author that these three stations (Winongo, Bantul, Palbapang) belonged to the small type stationsgebouw typology (Riza et al., 2017). This study aims to look at the characteristics of $18^{\text {th }}$ century Dutch-Indonesian architecture in the station building. This study is a follow-up study aiming to determine the architectural character of small type stations in Yogyakarta (spatial aspects, architectural aspects, structural aspects). Knowing the architectural character of the station building, it is hoped to become part of the conservation and preservation of cultural heritage buildings containing the historical value in Indonesia.

\section{Methods}

To identify answers to research problems and questions, this study employed a rationalisticqualitative approach. Qualitative research is planned activities containing a set of interpretive practices allowing the scope of respondents and informants to be seen (Denzin \& Lincoln, 2017). Assumptions in qualitative research are based on Lincoln, Guba, \& Publishing (Lincoln et al., 1985) about the nature of social reality (ontology) is subjective and plural according to the views of researchers and research subjects; about the relationship between researchers and research participants (epistemology). The process of qualitative research is inductive and open to various factors emerging in the society. The method used in this study aimed to reconstruct and find the characteristics of the station building.

This study employed a descriptive method as the data analysis by describing and providing an overview of each station's character viewed from the spatial system, architectural system, and building structure system. The explanation was derived from analyzing the history and environmental context that occurred at the station and the description of the building was derived from modeling the building so that the physical character of the station could be identified. The problem-solving procedure was derived from describing the current state of the research objects based on the facts as they were.

To obtain the characteristics of the station building, researchers used three architectural concepts, namely Vitruvius with firmitas, Venustas, and utilities (Pollio, 1914), Habraken's concept of three architectural systems (stylistic system, physical system, spatial system) (Habraken, 1979), and architectural system by DK Ching (Ching, 2014). From these concepts, a search on architectural characteristics will be divided according to the spatial system, architectural system, and structural system.

\section{Discussion}

Based on the gathered data, Winongo, Bantul, and Palbapang Station belong to small type stationsgebouw. The discussion of the building's characteristics will be divided according to the spatial system, architectural system, and structural system below.

\subsection{Spatial System}

Winongo, Bantul, and Palbapang Station belonged to small type stationsgebouw. They were categorized to a parallel type station based on the building's characteristics which had a railway track only on a single side of the building. This type allowed the passengers to get in and out of the train from one side only. The orientation of the building is facing the direction of the train's movement. In this case, the train moves from Yogyakarata to Bantul and vice versa causing the line to extend from north to south. Therefore, the building faced the direction of the train's motion. With the elongated building following the railroad track, the spaces formed will be more efficient and can function optimally (see figure 4.1). 

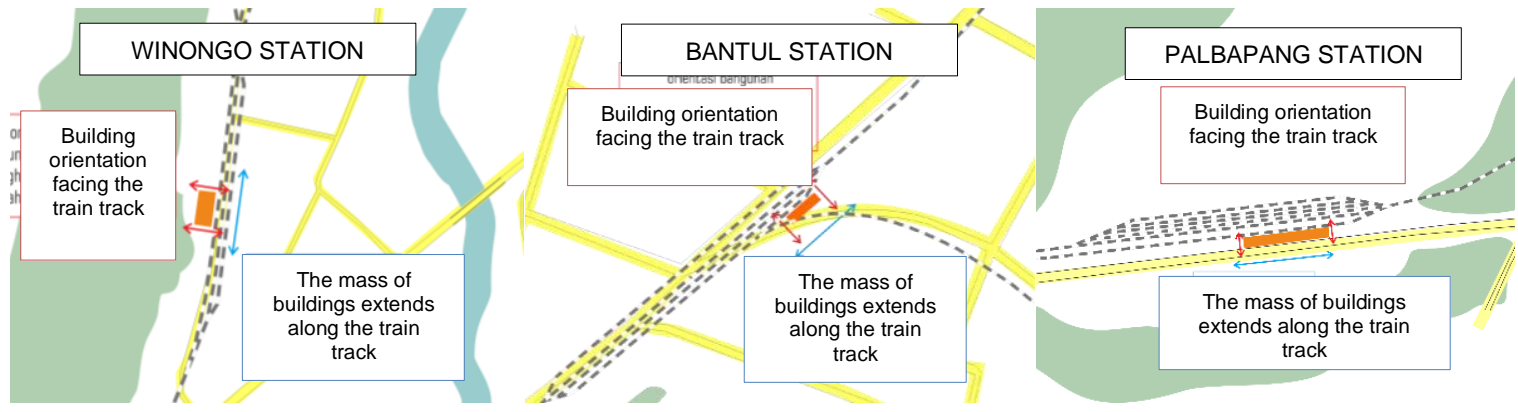

Figure 4.1 Setting of the Building (Authors, 2021)

The station building serves to accommodate trains and passengers, thus it has two orientations which are facing the railroad track and facing the direction of passengers' arrival. This choice of building orientation was influenced by the functional needs and rational thinking of Europeans who were not based on religious spirituality and mythological mentality, but rather on logical thinking instead (Mangunwijaya, 1994). At that time, this thought became a unique feature of buildings built by the Dutch government in Indonesia, where generally, buildings in Indonesia were strongly influenced by mental spirituality and religion. The role of space efficiency and the role of the spatial function of the station building is a top priority in determining the setting and orientation of the building. The three stations had a single building mass extending following the direction of the train's motion. Around the station emplacement area, there were supporting buildings such as the official housing complex for railway workers.

The station rooms were equipped with wachtkamer (platform), kantoor/kaarjtjees (office), condecteur (machinist room), and magajizn (warehouse). The hierarchy of these spaces was obtained as follows:

- Passenger public zone was indicated by wachtkamer.

- Officer administrative zone was indicated by kantoor/kartjees, and condecteur

- Train operational technical zone was indicated by magajizn

The spaces were arranged in a linear manner where the circulation pattern passing through the space was in the form of an open circulation on one side. The circulation of the building was carried out outside or on the terrace of the building facing the train tracks where this was also used as a platform for passengers to wait for the train. Therefore, the orientation of the spaces in the station was facing the terrace and was also directly facing the train tracks. This made the firmness of the arranged linear space more visible because the circulation space was outside the building. This linear organization was developed to emphasize the existence of a movement where the station focused on the movement of the train direction. Every activity and space function occurring on both inside and outside the station depended on the movement of the train. The arrangement of space placement could be seen on the following plan (see figures 4.2 and 4.3 ). 


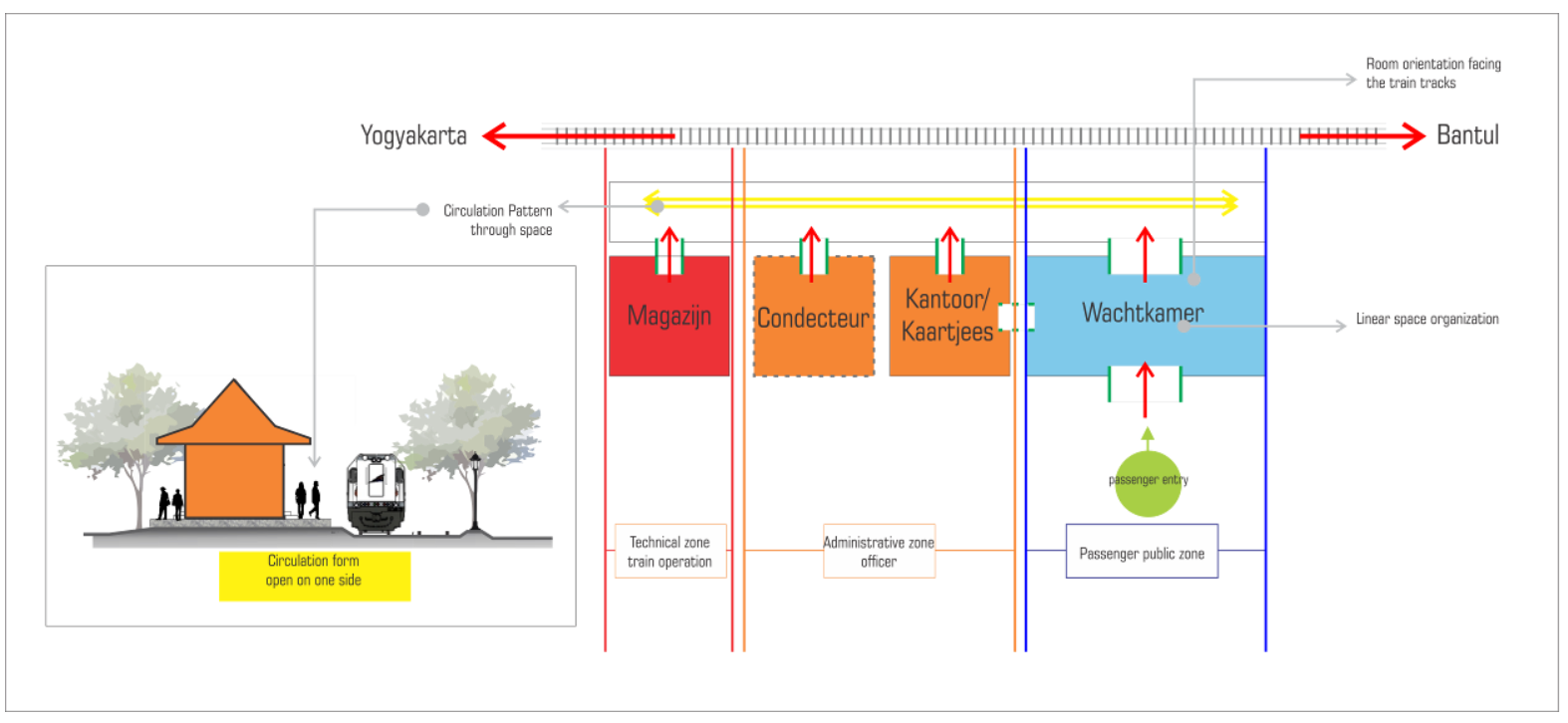

Figure 4. 2 Station's orientation, organization and circulation (Authors, 2021)

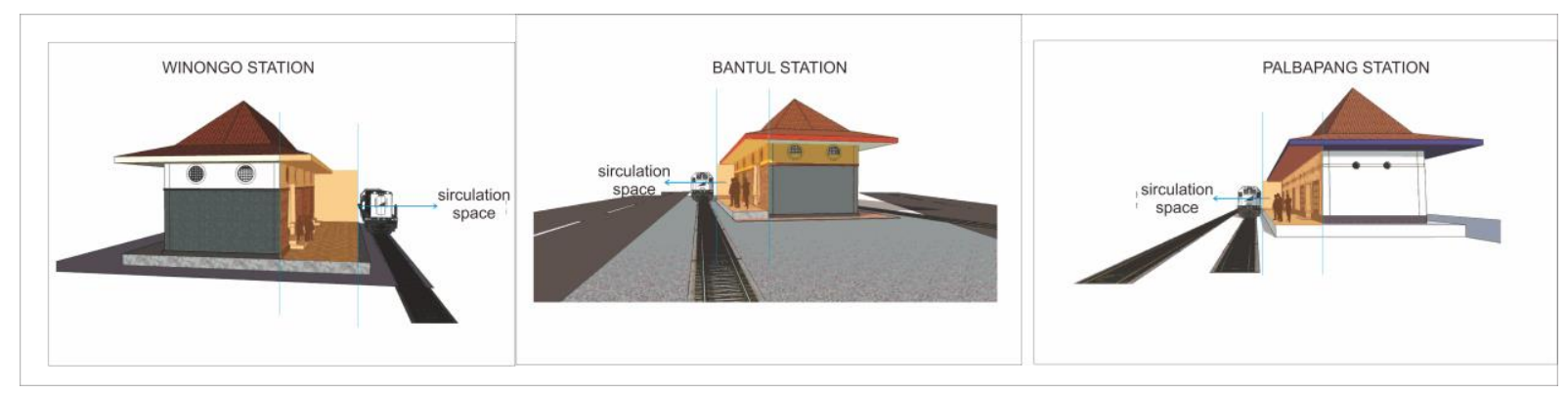

Figure 4. 1 Station's circulatiom form

The type of stationsgebouw found at Winongo, Bantul, and Palbapang Station had a wachtkamer with $6 \mathrm{~m} \times 4 \mathrm{~m}$ and $8 \mathrm{~m} \times 4 \mathrm{~m}$, and kantoor/kartjees with $4 \mathrm{~m} \times 4 \mathrm{~m}$ in size. The area of the wachtkamer was 2 times larger than the kantoor/kartjees room to remain comfortable even with many activities in it such as for welcoming passengers both from trains and from outside, waiting for train arrivals, and buying train tickets. From the results of the analysis, these stations had the same modular structure, which was formed from a $2 \mathrm{~m} \times 2 \mathrm{~m}$ module and then developed according to the space requirements of different stations. The use of this modular proportion was because the three buildings were strongly suspected to have undergone changes from their original buildings to meet the needs of the station function from the previous one. Modular proportions were thought to replace the previous proportions because they were easier to apply and to develop in shape to meet the needs of space functions (see figure 4.4). 


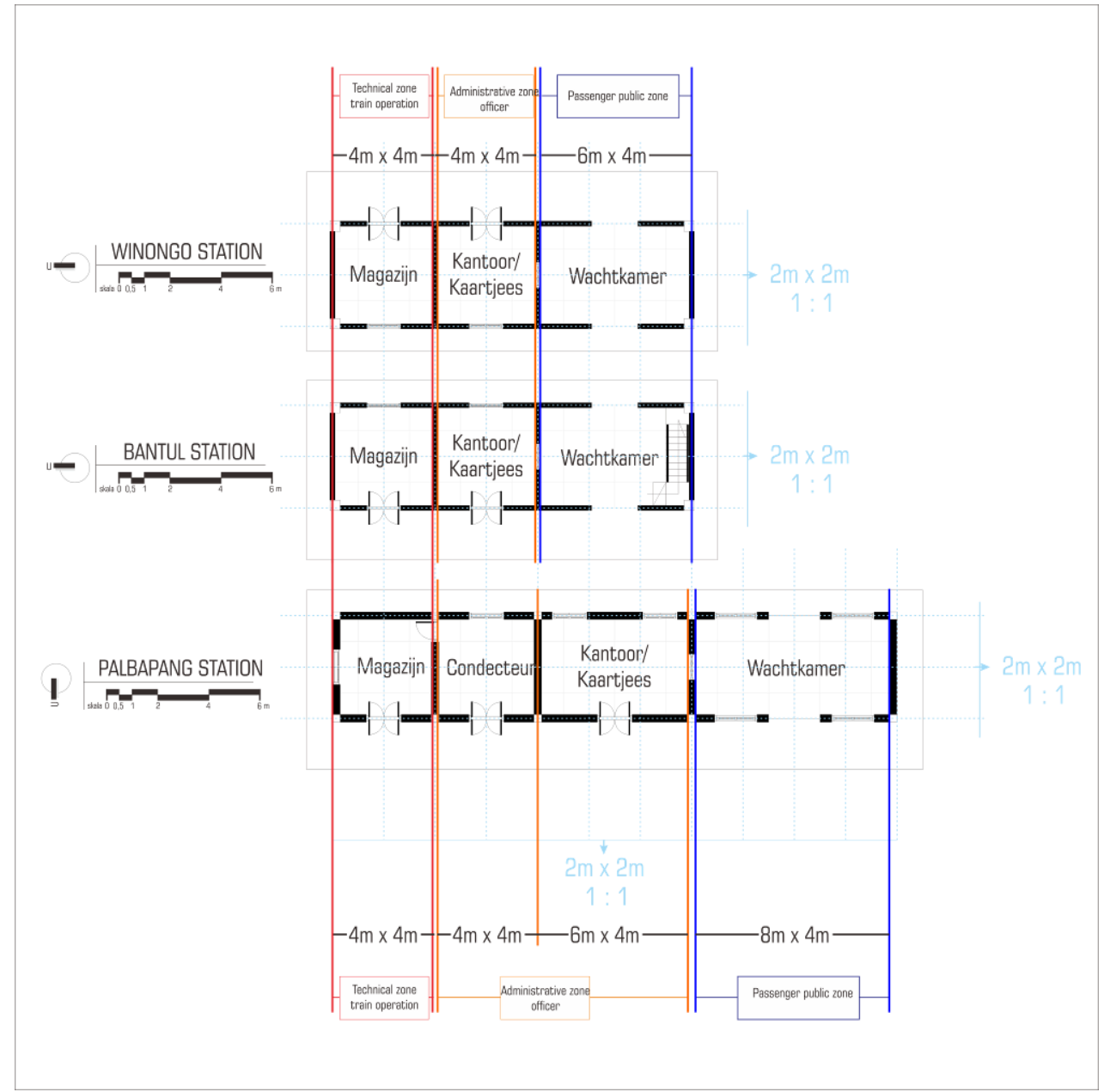

Figure 4. 4 Plans and proportions of the three station buildings (Authors, 2021)

Between adjacent spaces, there were dividing planes. The space separation using this plane aimed to maintain the level of continuity, both visual and spatial, between two adjacent spaces. It could be felt especially between the wachtkamer room and the office. There were openings such as windows that functioned as a ticket booth. At Winongo Station, the inner space dividing walls no longer exists due to changes made by local residents, but this information was obtained from resource persons around the station. The shape of the opening was unknown for certain, but from the results of the information, the opening wsa in the form of a wooden frame with a hole underneath. It was to limit physical and visual access between two adjacent spaces so as to strengthen the individuality of each space. With this counter window, visitors and office staff could still communicate with each other, but with limited physical and visual access, creating different space zones. In contrast to the counter, the space separation between the platform and the train lane was the difference in the floor elevation. The use of floor elevation without being limited by walls was able to provide a difference in space between the two spaces. Given the impression of 2 different zones without limiting physical or visual access so that passengers could maintain their activities around the platform without entering other areas. The height of the floor elevation is between $30-50 \mathrm{~cm}$ because the trains made in 1920 generally have stairs going down so that the platform floor was made lower than the train stairs to make it easier for passengers to enter the train (see figure 4.5) 


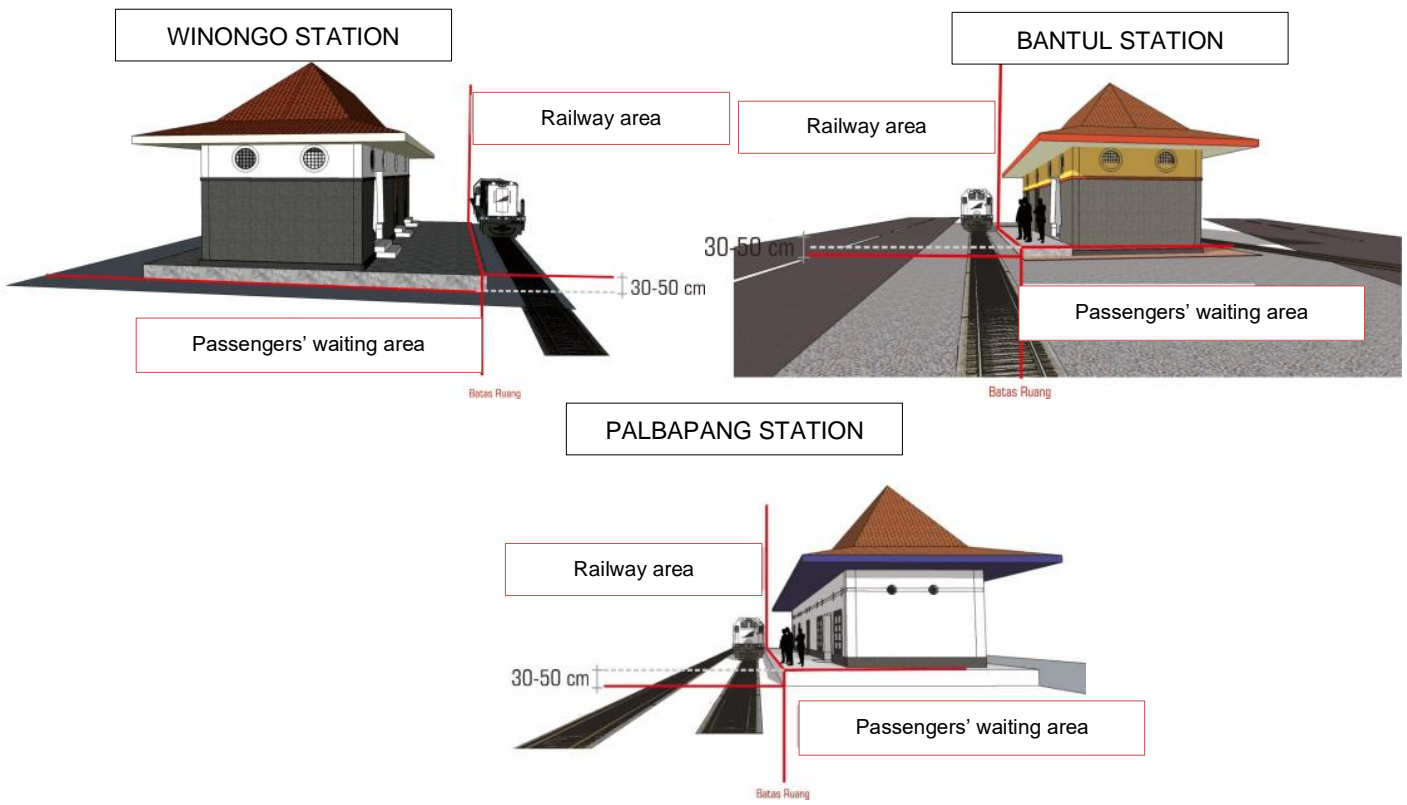

Figure 4. 5 Separation of train and passenger lines (Authors, 2021)

\subsection{Architectural System}

All of the three stations had a simple rectangular layout with a linear layout. This was what made the overall mass of the building a cubical shape. The cubical mass of the building had a rectangular base shape and extended along the railroad track (see figure 4.6). The shape of the buildings of these stations formed the balance of the facade. It was formed from a symmetrical facade system between opposite facade walls. The front facade was a reflection of the rear facade, as well as the side facades. It could be seen from the placement of door and window openings. The results of this reflection formed a symmetrical layout of the openings on each facade and created a balance in the shape of the building (see figure 4.7).

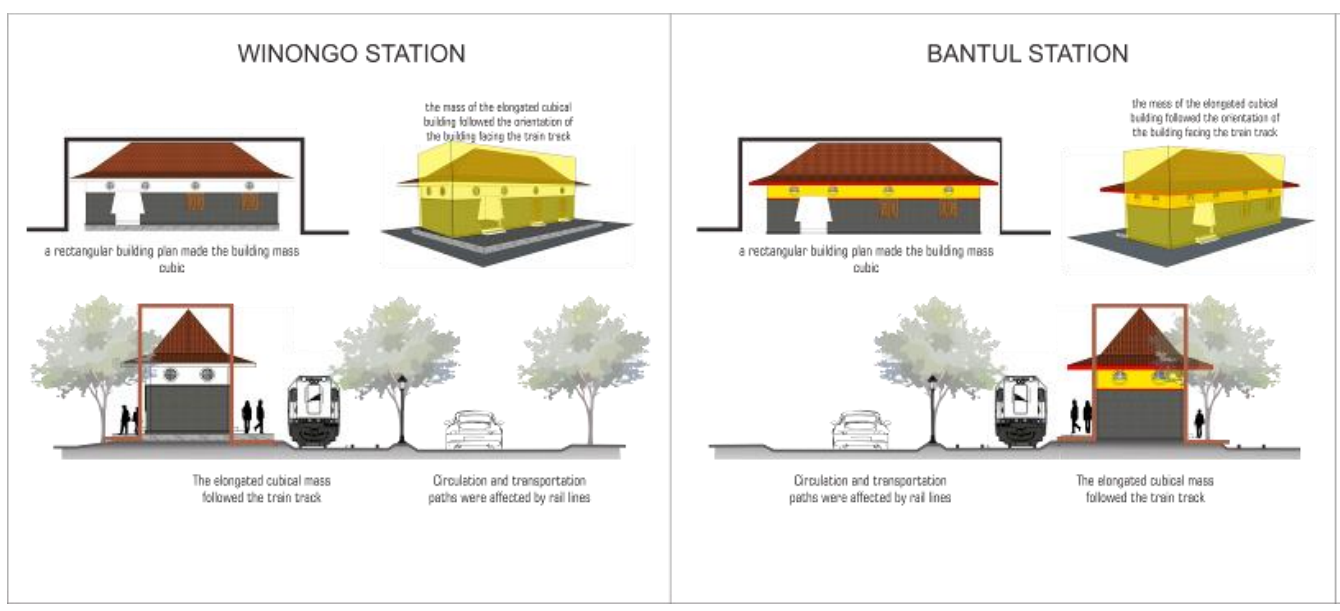




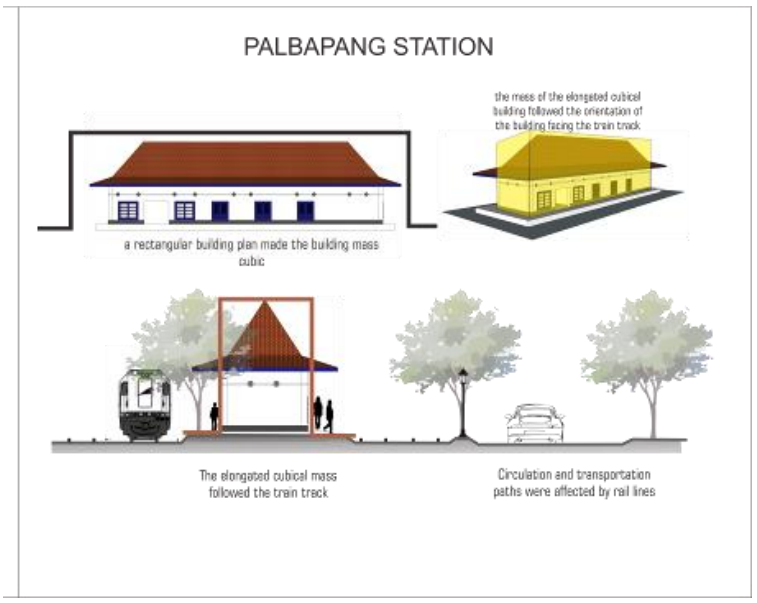

Figure 4. 6 The shape and form of the three stations (Authors, 2021)

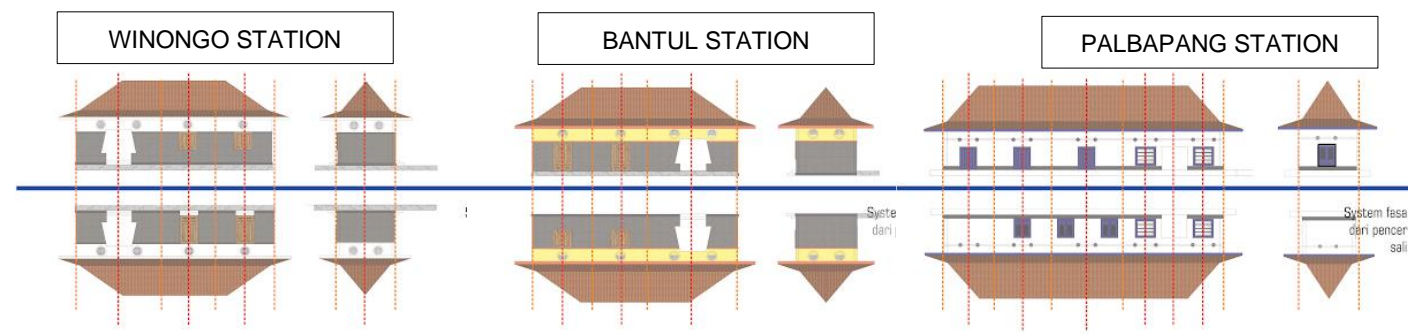

Figure 4. 7. The balance of the façade was formed from the symetrical façade system (Authors, 2021)

The roof of the three stations was a pyramid with a combination of joglo roofs with a height of $2.75-3.60 \mathrm{~m}$. The degree of roof slope ranged from 50-57 degrees. Based on the observations, this roof formation was a response to the climate in Indonesia which had high rainfall. For this reason, the side of the roof had an overhang with a width ranging from 1-1.5 $\mathrm{m}$ which was used to prevent splattered rainwater. The materials used were wooden gantries with clay tiles. The clay material on the tiles was used to absorb heat from the sun providing a comfortable temperature in the room below (see figure 4.8)

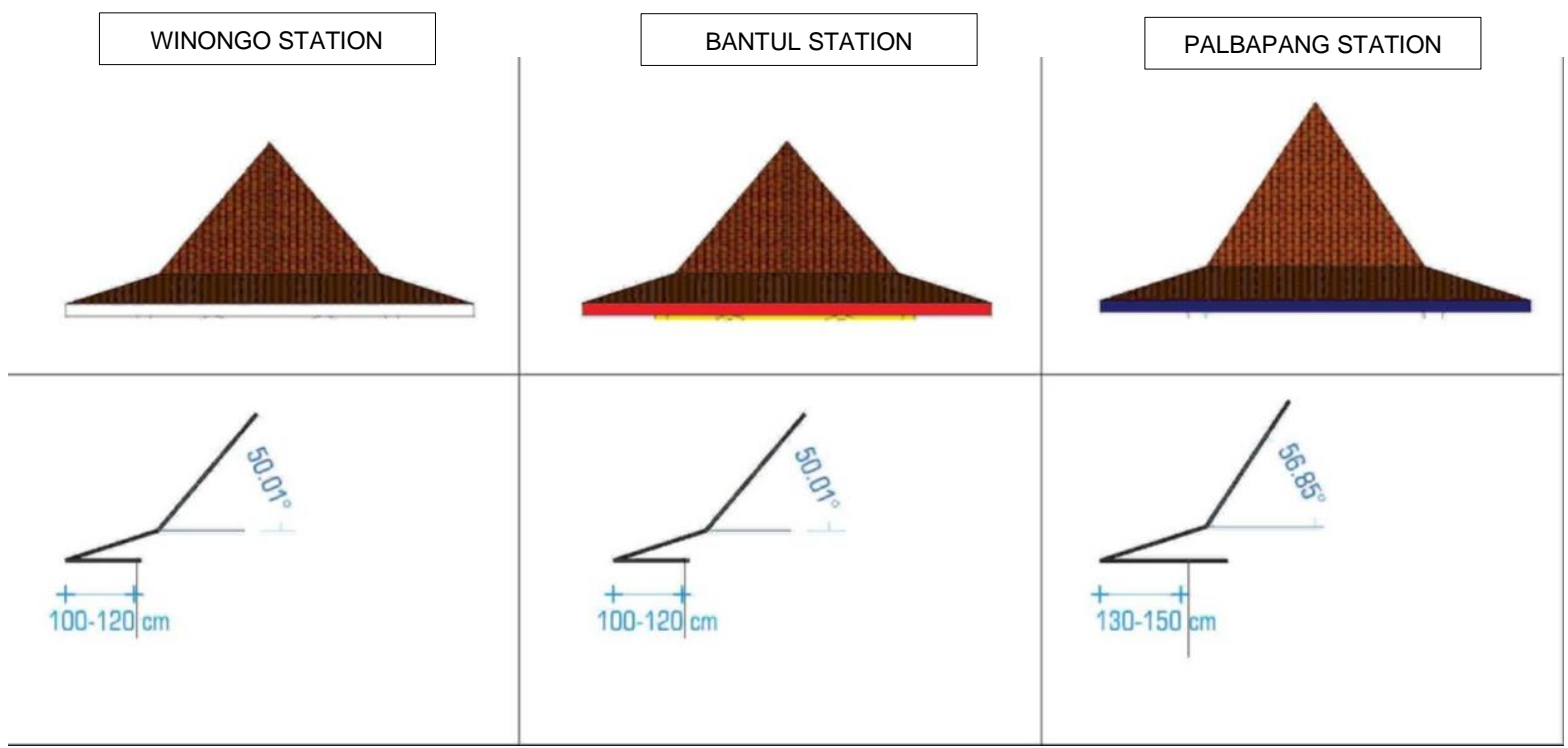

Figure 4. 8 The shape of the roof (Authors, 2021) 
The thickness of the station wall was $25-40 \mathrm{~cm}$ with double masonry. On the walls, there was a simple ornament in the form of a horizontal plane with a thickness between $2-5 \mathrm{~cm}$ and a diameter between $10-30 \mathrm{~cm}$. This horizontal ornament connected the boundary lines between one opening to another, so that it was like a helpline in maintaining each opening's height. The three stations were covered with brick walls and clay tile roofs so that overall, they had a solid texture. The door and window openings were dominated by wood material on the outside and a combination of glass on the inside. On the outer wall there was a layer of stone shards. On the facade of the station, the combination of different forms of door, window and ventilation openings was in a horizontal line. These horizontal lines were even done by adding them to the wall ornaments. This horizontal ornament gave the perception of a line in the plane of the wall connecting the edges of the opening to one another. In addition, to add to the harmony of the facade, the arrangement of circular ventilation was also not arbitrary. The vent was placed above the door/window on the center axis of the opening. For ventilation, the wachtkamer door was flanking the trapezium door.

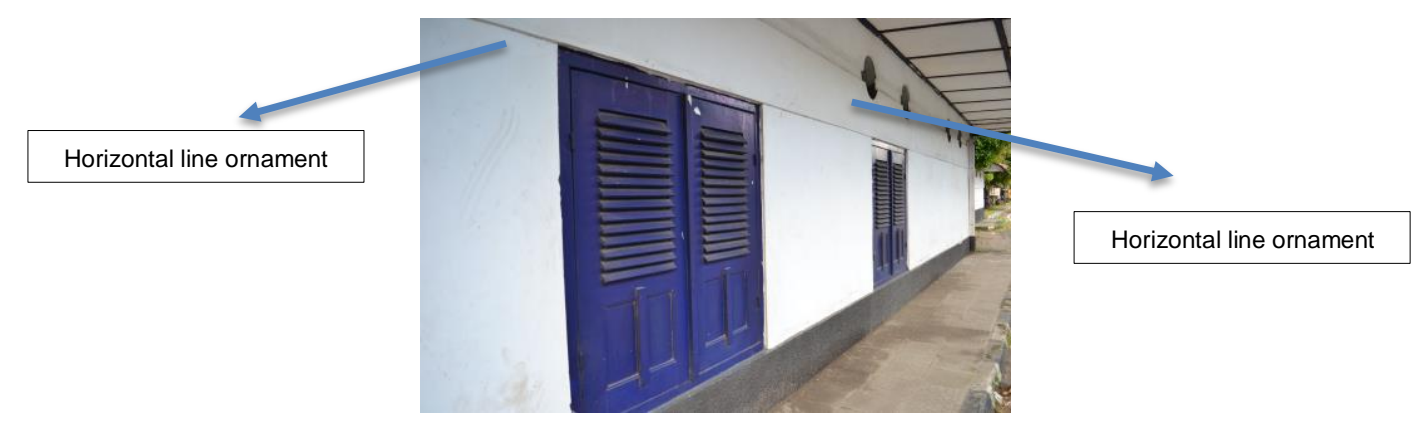

Figure 4. 9 Horizontal line ornament on the wall (Authors, 2021)

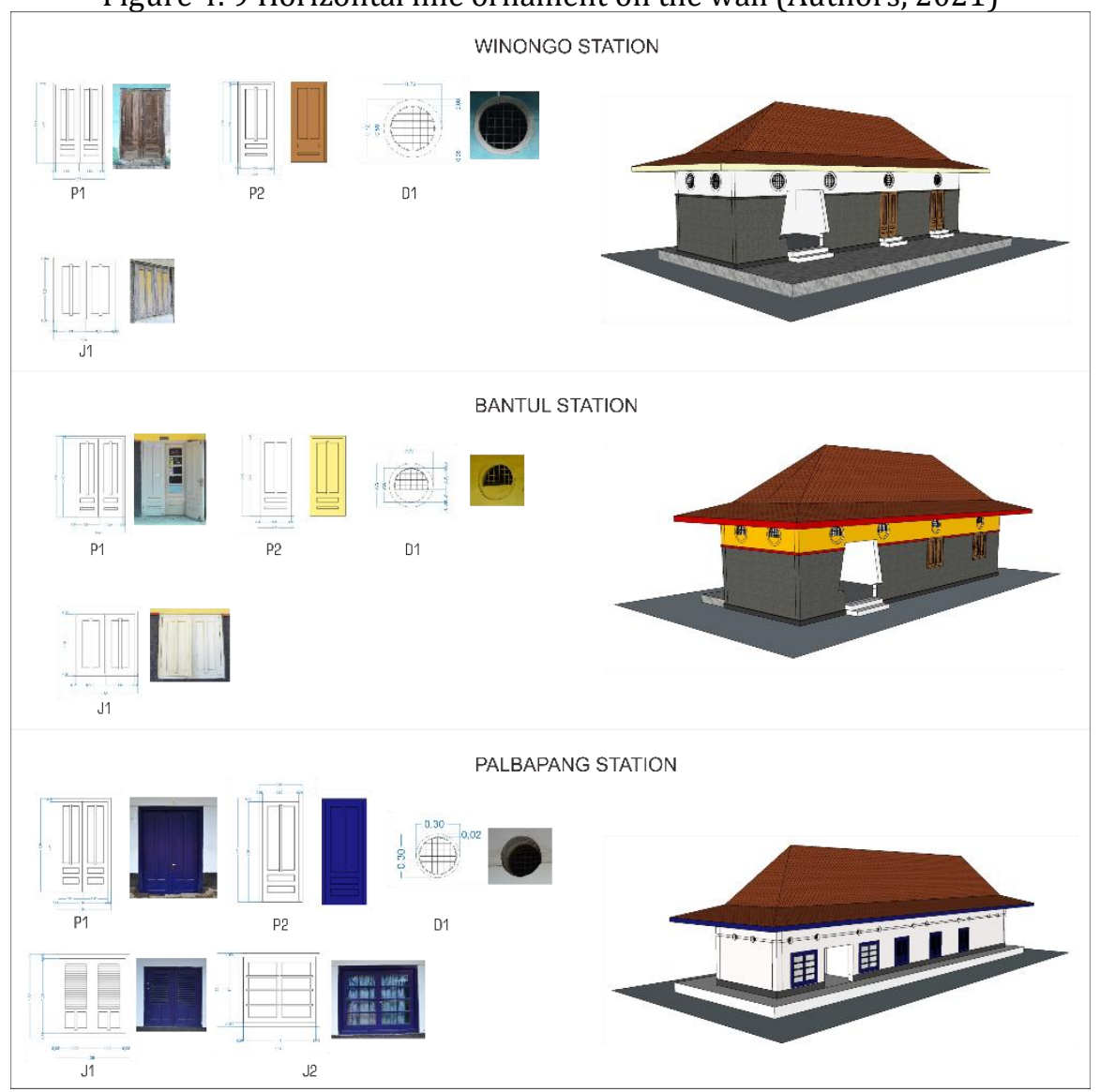

Figure 4. 10 Window and door openings at the station (Authors, 2021) 
From the results of observations, the three stations had the following door characteristics.

- The first door character (P1) was the connecting door to the office room. This door had 4 parts or commonly called the door blinds. The two outer blinds were made of wood with lattice holes, allowing air to enter but not light. While the two inner blinds were a combination of wood and glass materials, causing light to penetrate but air could not enter. These two different functions could be adjusted according to the conditions.

- The character of the second door (P2) was in the form of a connecting door between rooms in the building. This door was a solid wood material with 1 door blind.

Then from the results of observations, the three stations had the following window characters.

- The first window character ( $\mathrm{J} 1$ ) had 4 shutters or commonly called the window blind system similar to the door blind above.

- The second window character (J2) was a glass window with a wooden frame. This window was only in the wachtkamer area and in the form of a rigid window which could not be opened. It could only enter light from outside. This window character was only found in 1 station, Palbapang station.

- The character of the third window (D1) was a circular window covered with an iron trellis. This window served as ventilation.

One of the things that made this type of station a unique character was the main door. The main doors of the three stations were made with holes in the walls with trapezoidal and rectangular shapes so as to provide a sense of contrast to the overall facade. In addition, contrast was also felt in the circular shape of the ventilation holes.

\subsection{Structural System}

The building structure at this type of station was a closed frame structure which was a combination of the frame system and the construction of the supporting walls. The supporting wall was a thick wall ranging from $20-25 \mathrm{~cm}$ composed of plastered double masonry, the thickness of this wall served to transmit the load of the building from the roof to the foundation. Judging from the age of the buildings of these stations, the foundation used was a continuous foundation. It was in the form of an arrangement of bricks or a continuous arrangement of wood both horizontally and vertically since there was no development of concrete or beam technology as foundation reinforcement yet (Handinoto).

The roofs of this type of station building used a pyramid roof structure combined with a joglo roof. The roof structure frame used teak wood and the roof cover used brick tiles. The slopes of the roofs of these three stations range from 50-57 degrees. The roof structure consisted of wooden trusses connected by a ring balk placed on top of the wall. On the ring balk were arranged gording, ribs, battens, and clay tiles. On the roof structure was a walkway with a length of 1-1.2 meters from the outer wall. This walkway aimed to prevent rainwater splattered into the building. 


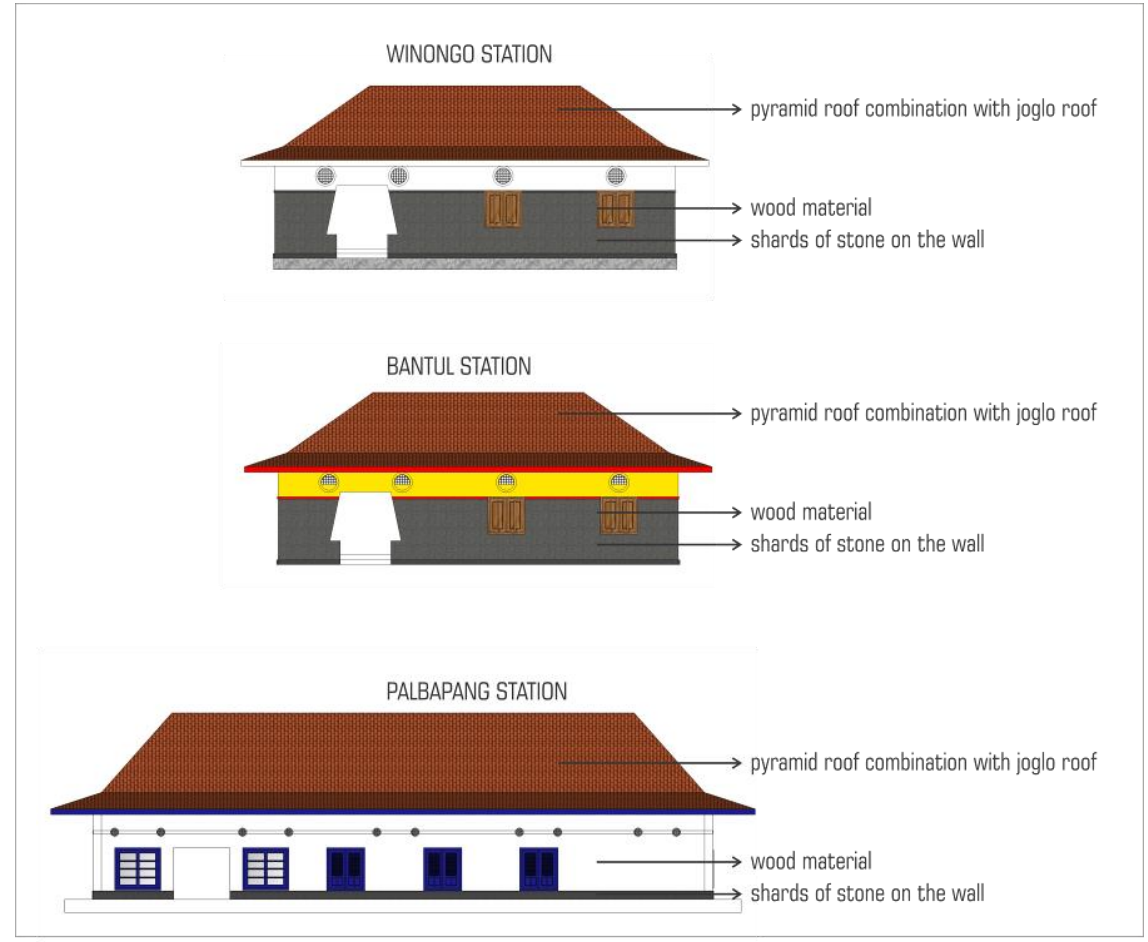

Figure 4. 11 Structural system on the station buiding (Authors, 2021)

Variations in the use of building materials were also found at the three stations. The building used a combination of local materials and modern materials at that time. Local materials were in the form of wood, stone fragments, and tiled roofs and modern materials were plastered bricks, glass, and tiles/ceramic. The use of wood materials was found on the frames and roof truss. The brick materials could be seen on the walls and columns of the building. The outer walls of the building were lined with stone chips. The roof of the building was tiles made of clay. The floor of the building used ceramic tiles which were arranged based on the size of the room. The opening used a combination of wood and glass materials. The system for laying door and window openings was a symmetrical reflection of the building's appearance. This system caused cross ventilation so that air could enter and exit easily to make the temperature in the room comfortable.

\section{Conclusion}

Winongo, Bantul, and Palbapang Station belonged to small type stationsgebouw. The station rooms were equipped with wachtkamer (platform), kantoor/kaaritjees (office), condecteur (machinist room), and magajizn (warehouse). The spaces were arranged in a linear manner where the circulation pattern passing through the space was in the form of an open circulation on one side. The circulation of the building was carried out outside or on the terrace of the building facing the train tracks, where this was also used as a platform for passengers to wait for the train. These stations had the same modular, which was formed from a $2 \mathrm{~m} \times 2 \mathrm{~m}$ module and then developed according to the space requirements of different stations. Between adjacent spaces, there were dividing planes. The space separation using this plane aimed to maintain visual and spatial continuity between two adjacent spaces.

All of the three stations had a simple rectangular layout with a linear layout. There was what made the overall mass of the building a cubical shape. The cubical mass of the building had a rectangular base shape and extended along the railroad track. The shape of the buildings of these stations formed the balance of the facade. It was formed from a symmetrical facade system between opposite facade walls. The roof of the three stations was a pyramid with a 
combination of joglo roofs with a height of $2.75-3.60 \mathrm{~m}$. The thickness of the station wall was $25-40 \mathrm{~cm}$ with double masonry. There was a simple ornament on the walls in the form of a horizontal plane with a thickness between $2-5 \mathrm{~cm}$ and a diameter between 10-30 cm. This horizontal ornament connected the boundary lines between one opening to another so that it was like a helpline in maintaining each opening's height. One of the things that made this type of station a unique character was the main door. The main doors of the three stations were made with holes in the walls with trapezoidal and rectangular shapes to provide a sense of contrast to the overall facade. In addition, the contrast was also felt in the circular shape of the ventilation holes.

The building structure at this type of station was a closed frame structure, a combination of the frame system and the construction of the supporting walls. The supporting wall was a thick wall ranging from $20-25 \mathrm{~cm}$, composed of plastered double masonry. The thickness of this wall served to transmit the load of the building from the roof to the foundation. The roofs of this type of station building used a pyramid roof structure combined with a joglo roof. The roof structure frame used teak wood, and the roof cover used brick tiles. The slopes of the roofs of these three stations range from 50-57 degrees. Variations in the use of building materials were also found at the three stations. The building used a combination of local materials and modern materials at that time. Local materials were wood, stone fragments, and tiled roofs, and modern materials were plastered bricks, glass, and tiles/ceramic.

From the results of the study, it was found that Winongo Station, Bantul Station, and Palbapang Station have a distinctive character both from the spatial system, architectural system, and structural system.

\section{References}

Denzin, N. K., \& Lincoln, Y. S. (2017). The SAGE Handbook of Qualitative Research. SAGE Publications. https://books.google.co.id/books?id=AmPgDQAAQBAJ

Lehner, E., Doubrawa, I., Ikaputra., IVA-ICRA, I. for C. R. in A. (Vienna)., \& Gadjah Mada University. Department of Architecture and Planning. (2013). Insular diversity: architecture, culture, identity in Indonesia. IVA-ICRA, Institute for Comparative Research in Architecture.

Lincoln, Y. S., Guba, E. G., \& Publishing, S. (1985). Naturalistic Inquiry. SAGE Publications. https://books.google.co.id/books?id=2oA9aWINeooC

Kompasiana. 2017. Pabrik Gula di Yogya Tidak Hanya PG Madukismo Halaman 1 https://www.kompasiana.com/lengkongsanggar/591fc8bafd22bd4c6d5f7327/pabrikgula-di-yogya-tidak-hanya-pg-madukismo

Purnomo, H., Waani, J. O., \& Wuisang, C. E. V. (2017). GAYA \& KARAKTER VISUAL ARSITEKTUR KOLONIAL BELANDA DI KAWASAN BENTENG ORANJE TERNATE. MEDIA MATRASAIN, 14(1), 23-33. https://ejournal.unsrat.ac.id/index.php/jmm/article/view/15443

Riza, M. A. A., Ikaputra, \& Wihardyanto, D. (2017). KARAKTERISTIK ARSITEKTUR BANGUNAN STASIUN NIS JALUR YOGYAKARTA-BANTUL. Universitas Gadjah Mada.

Sumalyo, Y. (1995). Arsitektur Kolonial Belanda Di Indonesia. vii-viiii, 1-237. 